\title{
Acute Correction of Congenital Brachymetatarsia in Adolescents and Young Adults
}

\author{
D. Keshet ${ }^{1}$, S. Salminen ${ }^{1,2}$, M. Eidelman ${ }^{1}$ \\ ${ }^{1}$ Pediatric Orthopedics, Ruth Children's Hospital, Rambam Health Care Campus, Haifa, Israel \\ ${ }^{2}$ Department of Pediatric Orthopaedics and Traumatology, University Clinic for Orthopedics and Rheumatology, \\ University of Trondheim (NTNU), St. Olavs Hospital, Trondheim, Norway
}

\begin{abstract}
Introduction. Brachymetatarsia is a relatively rare abnormal shortening of metatarsal bone with female predominance. No consensus exists about the ideal surgical treatment for this condition while the two common strategies are gradual lengthening using external fixation and acute one stage lengthening. We describe the surgical technique of acute lengthening using iliac bone graft and report our results. Materials and Methods. Twelve patients (11 females, one male) with 14 short metatarsals were treated in our hospital over a 12-year period. The mean age was 17.4 years (range 14-28 years). Treatment protocol included metatarsal osteotomy, lengthening of extensor tendon and percutaneous tenotomy of the flexor tendon at the level of affected MP joint. Autologous iliac bone graft was inserted after elongation of the metatarsal by distraction through the osteotomy site and fixed using Kirshner wire. Results. Average metatarsal shortening was $13 \mathrm{~mm}$ (range, 11-18 mm). The metatarsal length gained was an average of $12 \mathrm{~mm}$ (range, 11-15 mm). Uneventful bone union was achieved in all cases after six weeks. At the end of treatment, the normal cascade of the metatarsal heads (metatarsal parabola) had been restored in 11 of the 14 metatarsals treated. There were no wound complications or pin tract infections around the wire. All but one patient were satisfied with the cosmetic appearance of the foot. Conclusion. Based on our experience, acute metatarsal lengthening using an iliac autugraft is a reliable and effective treatment method for congenital brachymetatarsia in adolescents and young adults.
\end{abstract}

Level of Evidence: Level IV Case series.

Keywords: deformity, brachymetatarsia, acute correction.

doi: 10.21823/2311-2905-2019-25-3-84-89

\section{Одномоментная коррекция врожденной брахиметатарзии у подростков и пациентов молодого возраста}

\author{
Д. Кешет ${ }^{1}$, С. Салминен ${ }^{1,2}$, М. Эйдельман ${ }^{1}$ \\ ${ }^{1}$ Детское ортопедическое отделение, детская больница им. Рут Раппапорт, медицинский центр «Рамбам», \\ Хайфа, Израиль \\ ${ }^{2}$ Отделение детской ортопедии и травматологии, Университетская клиника ортопедии и ревматологии, \\ Университет Тронхейма, больница Святого Олафа, Тронхейм, Норвегия
}

\section{Реферат}

Введение. Брахиметатарзия является относительно редкой патологией аномального укорочения плюсневых костей, наиболее часто встречающейся у женщин. В настоящее время отсутствует консенсус в отношении идеального хирургического метода лечения данной деформации, и существуют две общепризнанные стратегии лечения: постепенное удлинение с использованием чрескостного остеосинтеза и одномоментное удлинение с применением аутотрансплантата. Авторы описывают хирургическую технику и приводят свои результаты выполнения одномоментной процедуры удлинения с использованием аутотрансплантата из гребня подвздошной кости. Материал и методы. За 12-летний период в клинике были прооперированы 12 пациентов (11 женщин, 1 мужчина) с укорочениями 14 плюсневых костей. Средний возраст пациентов 17,4 лет (от 14 до 28 лет). Протокол лечения включал остеотомию плюсневых костей, удлинение сухожилия

[D] Cite as: Keshet D., Salminen S., Eidelman M. [Acute Correction of Congenital Brachymetatarsia in Adolescents and Young Adults]. Travmatologiya $i$ ortopediya Rossii [Traumatology and Orthopedics of Russia]. 2019;25(3):84-89. doi: 10.21823/2311-2905-2019-25-3-84-89.

$\triangle$ Doron Keshet; e-mail: doron.keshet@gmail.com

Received: 19.07.2019. Accepted for publication: 27.08.2019. 
разгибателя и чрезкожную тенотомию сухожилия сгибателя на уровне деформированного пястно-фалангового сустава. Аутотрансплантат из гребня подвздошной кости помещали в область остеотомии после дистракции плюсневой кости и фиксировали спицами Киршнера. Результаты. Средняя величина укорочения плюсневых костей составляла 13 мм (в диапазоне от 11 до 18 мм). Средняя величина достигнутого удлинения составила 12 мм (в диапазоне от 11 до 15 мм). Костное сращение без осложнений у всех пациентов наблюдали через шесть недель. В результате лечения было восстановлено нормальное анатомическое соотношение головок плюсневых костей (плюсневая парабола) у 11 из 14 плюсневых костей. Авторы не наблюдали случаев осложнения заживления хирургической раны или инфекции в области введения спиц. За исключением одного все пациенты были удовлетворены эстетическим внешним видом стопы. Заключение. Исходя из опыта авторов, одноэтапное удлинение плюсневых костей с применением аутотрансплантата из подвздошной кости является надежным и эффективным методом лечения врожденной брахиметатарзии у подростков и пациентов молодого возраста.

Уровень доказательности: IV, серия клинических наблюдений.

Ключевые слова: деформация, брахиметатарзия, одномоментная коррекция.

\section{Introduction}

Brachymetatarsia is defined as a short metatarsal that ends more proximally to the parabolic arc of the metatarsal heads. It is a rare, female dominant disorder with an estimated incidence of $0.02-0.05 \%$ and a female to male ratio of up to $25: 1[1,2]$. The condition may be unilateral or bilateral and may involve one or more metatarsals.

Commonly, the mid metatarsals are affected, most frequently the fourth metatarsal [1-4]. The abnormally short ray is thought to be the result of retarded growth or premature closure of the epiphyseal plate. Although the exact etiology is not clear, congenital and acquired forms are recognized. The congenital form can be idiopathic, the most common form, or associated with other conditions, such as Turner's syndrome, Down's syndrome, sickle cell anemia or multiple epiphyseal dysplasia [2]. It may also be acquired as a result of trauma or surgery before epiphyseal closure [5]. In brachymetatrsia, the normal metatarsal parabola deforms and the toe of the involved metatarsal appears shorter (Fig. 1). This results in abnormal forefoot pressure distribution and accompanying transfer metatarsalgia, shoe irritation, callosities and cosmetic issues [6-8]. Brachymetatarsia and its accompanying complaints increase in severity until bone maturity is reached.

Conservative treatment with metatarsal pads, orthotics, toe splinting, and accommodative shoe wear is usually ineffective. Improvement of function and cosmetics can be achieved by surgery. Two principal treatment strategies are commonly applied, the first is acute lengthening using a graft (autograft or allograft) and the second is distraction osteogenesis with external fixation [1-5]. The purpose of surgical reconstruction is resolution of pain, proper forefoot alignment and function and improvement of cosmetic appearance $[9,10]$.

Each strategy has its benefits and drawbacks. Gradual lengthening with external fixation has been suggested for lengthening more than $1.5 \mathrm{~cm}$. The pro- cedure is done through an open osteotomy or percutaneously [5, 10-19]. There are a number of significant advantages described using callus distraction. Gradual correction allows unlimited length gain and reduces the risk of neurovascular structure stretching, it allows earlier weight bearing and it eliminates the need of autologous bone grafting and the accompanying donor site morbidity. The disadvantages of gradual correction include the risk of pin tract infection, adjacent joint stiffness, subluxation or axial deviation of the metatarsophalangeal joint, prolonged time to bone union, subsequent prolonged treatment course and the risk of premature callus consolidation. In addition, poor patient tolerance with external fixation devices contributes to lower satisfaction rates [10,11, 13-18].

The advantage of one-stage lengthening is the shorter period to bone union and hence shorter treatment course. There is less morbidity and higher compliance with acute correction [10, 12, 20, 21]. Possible disadvantages include donor-site morbidity, neurovascular impairment including ischemia of the toe caused by rapid stretching, limited length gain (13-15 $\mathrm{mm}$ ) and delayed or nonunion of the graft $[1,6,7,20,21,22,23,24]$.
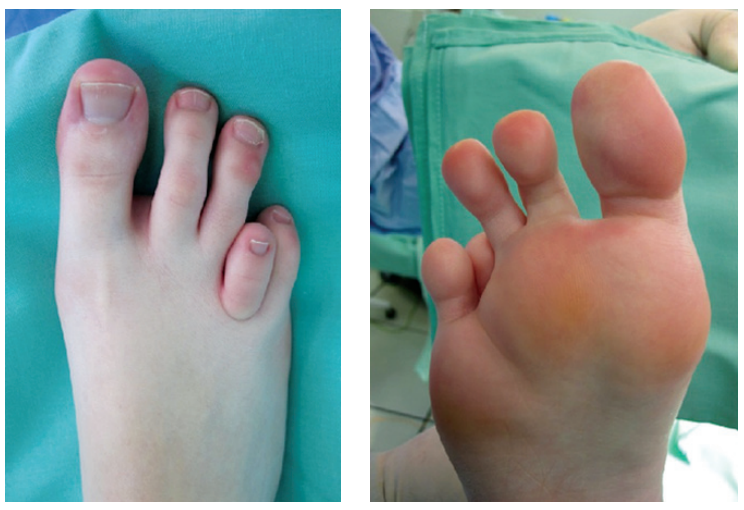

Fig. 1. Clinical appearance of $4^{\text {th }}$ toe brachmetatarsia 
The purpose of this study was to describe the surgical technique of acute lengthening using iliac autograft and to evaluate our results.

\section{Materials and Methods}

Twelve patients ( 11 female, one male) with 14 short metatarsals were treated in our hospital over a 12 year period. One of the patients had bilateral 4th metatarsal shortening and one patient had two metatarsal bones $\left(3^{\text {rd }}\right.$ and $\left.4^{\text {th }}\right)$ involved in the same foot. Mean age at surgery was 17.4 years (range, $14-28$ years), and all patients had reached skeletal maturity by the time of treatment.

\section{Surgical technique}

Patients were placed in the supine position and a sterile tourniquet (Hemaclear, OHK, Israel) was applied. A straight dorsal approach was used to expose the base of the relevant metatarsal bone. In order to prevent stretching of adjacent soft tissues and to eliminate deforming factors, $\mathrm{Z}$ lengthening of the extensor tendon was performed followed by percutaneous flexor tenotomy at the metatarsophalangeal joint level (Fig. 2). The level of desired osteotomy was marked at the base of the metatarsal using fluoroscopy, and an oscillating saw was used to make a transverse osteotomy. The next step was insertion of a $1.6 \mathrm{~mm}$ Kirshner Wire (KW) (sharp-pointed at both ends) through the metatarsal shaft towards the center of the tip of the toe (Fig. 3) as preparation for bone graft insertion and fixation.

Gradual gentle distraction using a laminar spreader or a Hintermann retractor was used to elongate the bone through the osteotomy gap to a clinically and radiographically desired length (Fig. 4). At this stage the sterile tourniquet was removed for careful examination of the vascular status of the toes. We used a 3 -cortical bone graft harvested from the iliac bone in the desired dimensions, followed by reshaping and resizing the graft to accommodate the width of the metatarsus bone and the desired length. After insertion of

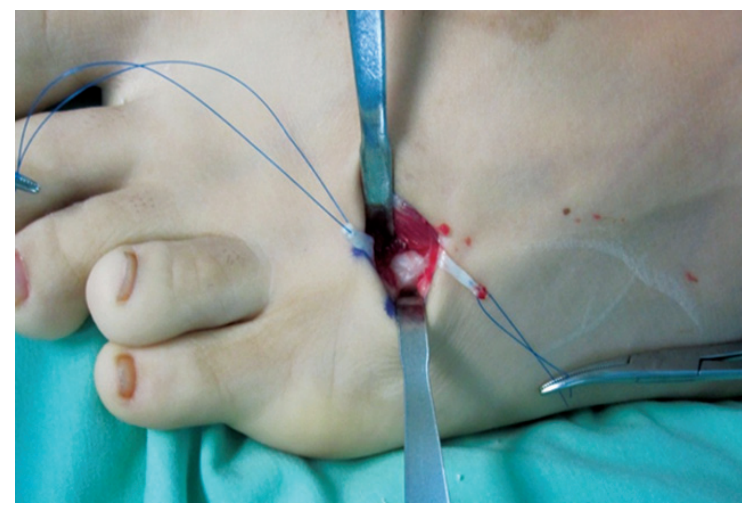

Fig. 2. Z-lengthening of the $4^{\text {th }}$ toe extensor tendon the autograft, the KW was used to fixate the graft to the proximal metatarsal and, after fluoroscopic verification of the correct position in both planes, the wire was driven to the tarsal bone (Fig. 5). The extensor tendon was sutured in the desired length followed by wound closure.

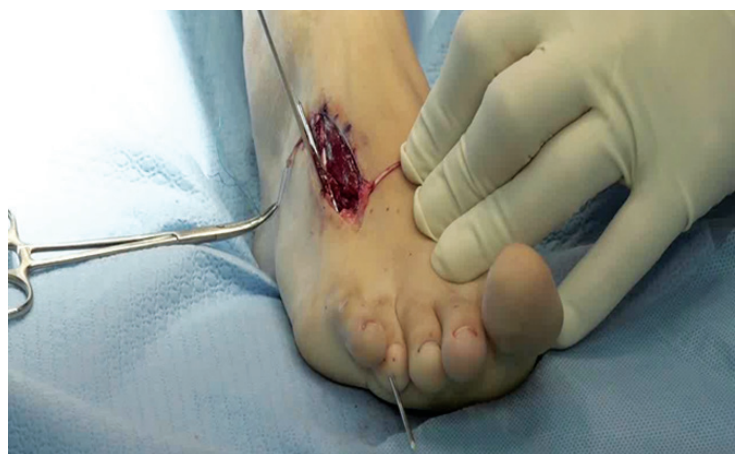

Fig. 3. 1.6 mm Kirshner wire inserted through the metatarsal shaft toward the center of the tip of the toe

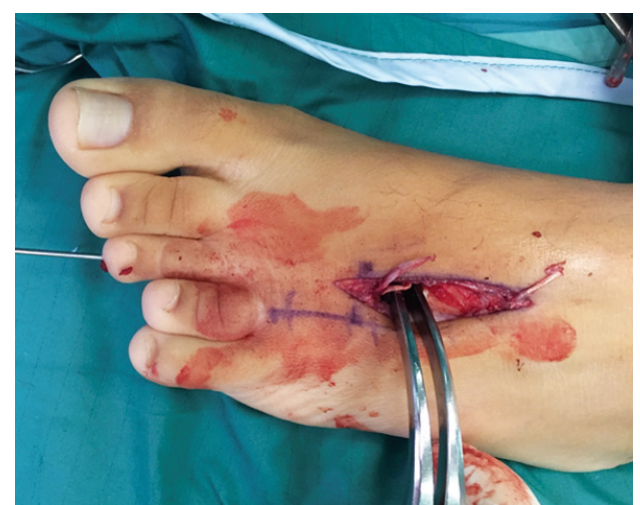

Fig. 4. Acute lengthening of the metatarsal through the osteotomy gap using a laminar spreader. Note the position of the retrograde Kirshner wire inserted in preparation for graft fixation

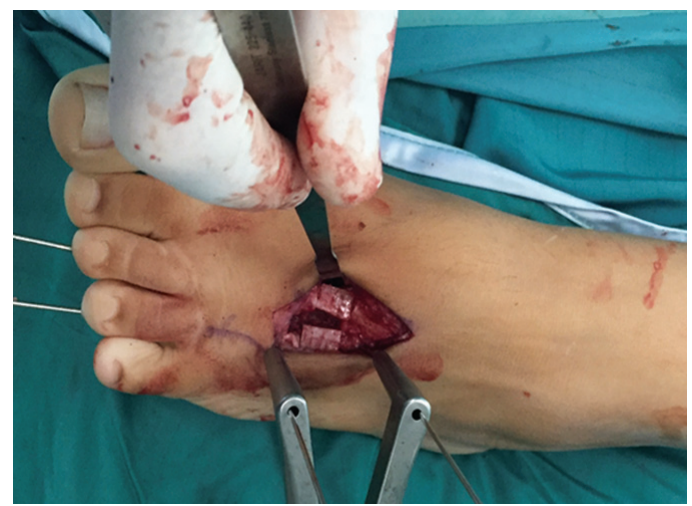

Fig. 5. $3^{\text {rd }}$ and $4^{\text {th }}$ brachymetatarsia. Iliac crest bicortical autograft was harvested and reshaped to fit the desired length and width of the metatarsus. Autograft fixated with the Kirshner wire to the proximal metatarsus and tarsal bone 
In several cases, additional extensor tendon release was required in adjacent toes as a result of cockup deformities after elongation of the metatarsal. Our postoperative protocol included below knee cast application with no weight bearing for six weeks. After removal of the cast and the KW, partial gradual weight bearing was allowed.

\section{Results}

All the cases of brachymetatarsia in this series were congenital and idiopathic. Average metatarsal shortening was $13 \mathrm{~mm}$ (range, 11-18 $\mathrm{mm}$ ). Preoperative complaints were pain in $83 \%$ of the cases, difficulties with wearing shoes in $66 \%$ of cases, and concerns of
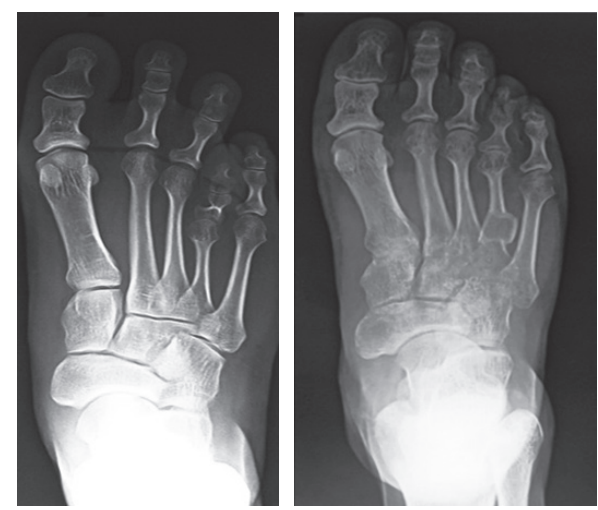

Fig. 6. Preoperative radiographs demonstrate the altered metatarsal parabola and typical shortening of the toe. Postoperative radiographs demonstrate good bone union of the graft with restored parabola and deformity correction
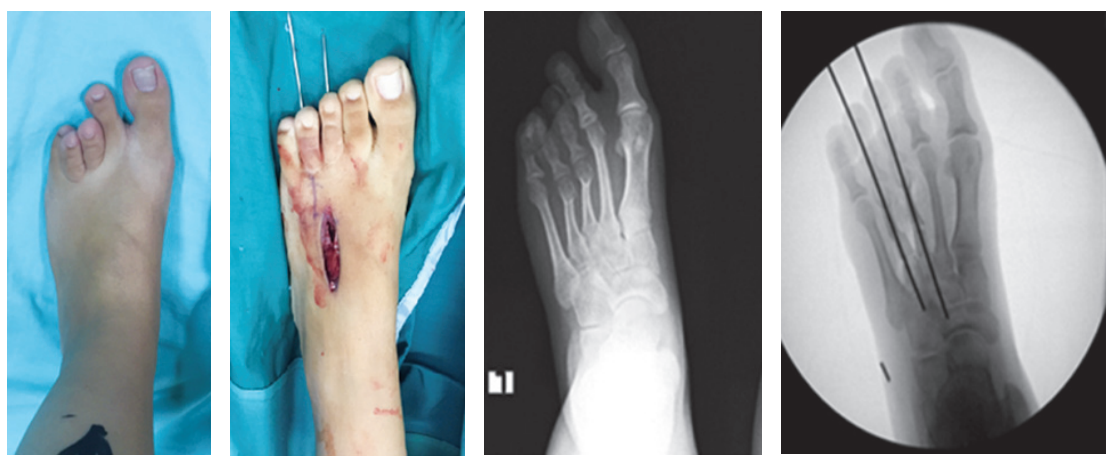

Fig. 7. Preoperative and intra-operative radiographs of $3^{\text {rd }}$ and $4^{\text {th }}$ toe brachymetatarsia poor cosmetic appearance were reported by all patients treated (100\%).

The metatarsal length gained was an average of $12 \mathrm{~mm}$ (range, $11-15 \mathrm{~mm}$ ). No stiffness or subluxation of the metatarsophalangeal joint was recorded and there were no reports of significant postoperative pain. Uneventful bone union was achieved in all cases after six weeks. At the end of treatment, the normal cascade of the metatarsal heads (metatarsal parabola) had been restored in 11 of the 14 metatarsals treated (Fig. 6, 7). There were no wound complications or pin tract infections around the wire, and no neurovascular impairment. All but one patient were satisfied with the cosmetic appearance of the foot (Fig. 8).

\section{Discussion}

Brachymetatarsia is a relatively rare clinical entity of the foot that causes clinical disability and cosmetic discomfort for the patient and might pose a challenge for treatment. Although the patient may have complaints regarding pain and discomfort in the affected foot, the most common concern that urges the patient to seek a surgical solution is that of cosmetic appearance of the foot. The two surgical solutions that are most commonly used to treat this condition are acute lengthening using bone graft, and gradual, prolonged distraction based on stepwise lengthening with external fixation.

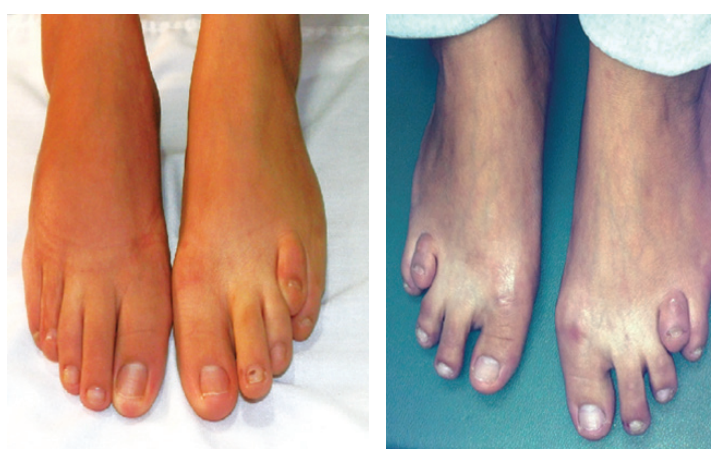


There are several inherent advantages and drawbacks described for each of the methods. The surgical solution should be chosen with respect to the specific patient's condition and expectations, including the age of the patient, the desired lengthening, the status of the soft tissues including adjacent joints of the foot, and the expected compliance with prolonged external fixation treatment. Careful patient selection and adjustment of treatment are prerequisites for success of treatment [25].

Since McGlamry and Cooper developed the technique of acute lengthening with bone graft, it has been shown in several studies that it can be safely used in metatarsals that need to be lengthened up to $15 \mathrm{~mm}$ [26]. The advantages of this method are mainly the short period of time needed for treatment and not requiring external fixation. The most significant drawbacks of acute correction are the limited length gain possible, the risk of neurovascular impairment, and donor site morbidity. Gradual correction using the principles of distraction osteogenesis can be safely used for metatarsals that need to be lengthened more than $15 \mathrm{~mm}$. This method allows early weight bearing and no donor site morbidity. Drawbacks include possible pin tract infection, stiffness and instability of adjacent joints. Both methods have been evaluated and reported in several studies $[1,2,5,15,17,20,21$, 22, 27, 28].

A comparison between both surgical methods was made by Choi et al who treated 15 metatarsals by acute elongation with an autologous graft and 9 metatarsals by gradual lengthening with callotasis. Results were comparable in terms of functional outcome, cosmetic appearance and satisfaction rate. The only statistical difference noted was the time needed for bone consolidation, which was shorter in the acute lengthening group [27].

Jones et al performed a comprehensive review of all published data concerning the results of acute lengthening with a bone graft versus gradual distraction. These authors included 761 short metatarsals in 61 different studies in the review, and surgical methods were compared in regard to demographics, surgical results and complication rates. In regards to length gain. it was clearly shown that metatarsals were lengthened more with gradual distraction compared to acute lengthening $(17.5 \mathrm{~mm}$ and $13.3 \mathrm{~mm}$, respectively) with higher percentages of metatarsal lengthening (37.36\% and $25.98 \%$, respectively). According to this review, gradual distraction took almost twice the time needed for healing, partially due to more extensive lengthening. It was clearly shown that major and minor complication rates were higher among patients undergoing callus distraction, most commonly stiffness at the MTP joint and subluxation of the treated metatarsal. Interestingly, neurovascular compromise which is commonly discussed as a major risk in acute lengthening was not mentioned in the studies reviewed by these authors [28].

In their series of 34 metatarsal undergoing acute lengthening with an autograft, Baek et al used deliberate gradual distraction through the osteotomy site for 20-30 minutes to avoid neurovascular compromise [20]. We believe that careful, monitored distraction during acute lengthening, with careful inspection of toe viability and color, as in our study, is safe as long as the metatarsal is not over-lengthened. Furthermore, we performed $\mathrm{Z}$ lengthening of the extensor tendon and flexor tenotomy in all cases, which further reduces soft tissue tensioning and the subsequent risk of neurovascular impairment and stiffness.

Giannini et al used an allograft for one stage lengthening and reported good results of 50 short metatarsals treated, with a mean lengthening of $13 \mathrm{~mm}$ and no incidence of soft tissue stretching or neurovascular impairment. The authors postulated that lengthening should not be more that $23 \%$ of the metatarsal length. Despite the fact that in some cases the metatarsal parabola was not perfectly restored, the majority of patients were satisfied with the results. These authors allowed all patients to bear weight on their hindfoot immediately after surgery with a special shoe [2]. In the current study. we used an iliac autograft and achieved similar gain of length (average $12 \mathrm{~mm}$ ). We had no incidence of complication in regard to the donor site, and very minimal morbidity. Our post-operative protocol differed by casting all treated feet and not allowing weight bearing for six weeks, assuming that it would be safer for graft position and bone healing.

In conclusion, based on our experience, acute metatarsal lengthening using an iliac autugraft is a reliable and effective treatment method for congenital brachymetatarsia in adolescents and young adults. We believe that it has less complications and a shorter healing time compared to gradual correction. Even in the cases in which the metatarsal parabola was not perfectly restored, good functional and cosmetic results were achieved.

\section{Publication ethics}

Disclosure of potential conflicts of interest: Doron Keshet, Sari Salminem and Mark Eidelman declare that they have no conflict of interest.

Funding: This study was not funded in any form.

Ethical approval: All procedures performed in studies involving human participants were in accordance with the ethical standards of the institutional and/ or national research committee and with the 1964 Helsinki declaration and its later amendments or comparable ethical standards.

Informed consent: Informed consent was obtained from all individual participants included in the study. 


\section{References}

1. Wada A., Bensahel H., Takamura K., Fukii T., Yanagida H., Nakamura T. Metatarsal lengthening by callus distraction for brachymetatarsia. J Pediatr Orthop $B$. 2004;13(3):206-210.

2. Giannini S., Faldini C., Pagkrati S., Miscione M.T., Luciani D. One-stage metatarsal lengthening by allograft interposition: a novel approach for congenital brachymetatarsia. Clin Orthop Relat Res. 2010;468(7):1933-1942. doi: 10.1007/s11999-009-1212-0.

3. Urano Y., Kobayashi A. Bone-lengthening for shortness of the fourth toe. J Bone Joint Surg Am. 1978;60(1):91-93.

4. Mah K.K., Beegle T.R., Falknor D.W. A correction for short fourth metatarsal. I Am Podiatr Med Assoc. 1983;73(4):196-200. doi: 10.7547/87507315-73-4-196.

5. Shim J.S., Park S.J. Treatment of brachymetatarsia by distraction osteogenesis. J Pediatr Orthop. 2006;26(2): 250-254. doi: 10.1097/01.bpo.0000214922.18186.06.

6. Davidson R.S. Metatarsal lengthening. Foot Ankle Clin. $2001 ; 6(3): 499-518$

7. Kim J.S., Baek G.H., Chung M.S., Yoon P.W. Multiple congenital brachymetatarsia. A one-stage combined shortening and lengthening procedure without iliac bone graft. J Bone Joint Surg Br. 2004;86(7):1013-1015.

8. Takakura Y., Tanaka Y., Fujii T., Tamai S. Lengthening of short great toes by callus distraction. J Bone Joint Surg Br. 1997;79(6):955-958.

9. Fox I.M. Treatment of brachymetatarsia by the callus distraction method. I Foot Surg. 1998;37(5):391-395.

10. Scher D.M., Blyakher A., Krantzow M. A modified surgical technique for lengthening of a metatarsal using an external fixator. HSSJ. 2010;6(2):235-239. doi: 10.1007/s11420-010-9160-5.

11. Magnan B., Bragantini A., Regis D., Bartolozzi P. Metatarsal lengthening by callotasis during the growth phase. J Bone Joint Surg Br. 1995;77(4):602-607.

12. Robinson J.F., Ouzounian T.J. Brachymetatarsia: congenitally short third and fourth metatarsals treated by distraction lengthening -- a case report and literature summary. Foot Ankle Int. 1998;19(10):713-718. doi: 10.1177/107110079801901012.

13. Lamm B.M. Percutaneous distraction osteogenesis for treatment of brachymetatarsia. J Foot Ankle Surg. 2010;49(2):197-204. doi: 10.1053/i.jfas.2009.09.005.

14. Upton J., Khouri R., Ramos D., Micheli L. Distraction lengthening for the congenitally short metatarsal: a case report. Foot Ankle. 1989;10(3):184-187.

15. Song H.R., Oh C.W., Kyung H.S., Kim S.J., Guille J.T., Lee S.M., Kim PT. Fourth brachymetatarsia treated

\section{СВЕДЕНИЯ ОБ АВТОРАХ}

Дорон Кешет - д-р медицины, детское ортопедическое отделение, детская больница им. Рут Раппапорт при медицинском центре «Рамбам», Хайфа, Израиль

Сари Салминен - д-р медицины, детское ортопедическое отделение, детская больница им. Рут Раппапорт при медицинском центре «Рамбам», Хайфа, Израиль; отделение детской ортопедии и травматологии, Университетская клиника ортопедии и ревматологии, Университет Тронхейма, больница Святого Олафа, Тронхейм, Норвегия

Марк Эйдельман - д-р медицины, руководитель детского ортопедического отделения, детская больница им. Рут Раппапорт при медицинском центре «Рамбам», Хайфа, Израиль with distraction osteogenesis. Foot Ankle Int. 2003; 24(9):706-711. doi: 10.1177/107110070302400910.

16. Yamada N., Yasuda Y., Hashimoto N., Iwashiro H., Uchinuma E. Use of internal callus distraction in the treatment of congenital brachymetatarsia. Br J Plastic Surg. 2005;58(7):1014-1019. doi: 10.1016/j.bjps.2005.04.042.

17. Lee K.B., Park H.W., Chung J.Y., Moon E.S., Jung S.T., Seon J.K. Comparison of the outcomes of distraction osteogenesis for the first and fourth brachymetatarsia. J Bone Joint Surg Am. 2010;92(16):2709-2018. doi: 10.2106/JBJS.I.00338.

18. Wakisaka T., Yasui N., Kojimoto H., Takasu M., Shimomura Y. A case of short metatarsal bones lengthened by callus distraction. Acta Orthp Scand. 1988;59(2):194-196.

19. Saxby T., Nunley J.A. Metatarsal lengthening by distraction osteogenesis: a report of two cases. Foot Ankle. 1992;13(9):536-539.

20. Baek G.H., Chung M.S. The treatment of congenital brachymetatarsia by one-stage lengthening. J Bone Joint Surg Br. 1998;80(6):1040-1044.

21. Kim H.T., Lee S.H., Yoo C.I., Kang J.H., Suh J.T. The management of brachymetatarsia. J Bone Joint Surg Br. 2003;85(5):683-690.

22. Levine S.E., Davidson R.S., Dormans J.P., Drummond D.S. Distraction osteogenesis for congenitally short lesser metatarsals. Foot Ankle Int. 1995;16(4):196-200. doi: 10.1177/107110079501600405

23. Blankenhorn B.D., Kerner P.J., DiGiovanni C.W. Clinical tip: one-stage lengthening of fourth brachymetatarsia using fibular autograft. Foot Ankle Int. 2010;31(2): 175-178. doi: 10.3113/FAI.2010.0174.

24. Alter S.A., Feinman B., Rosen R.G. Chevron bone graft procedure for the correction of brachymetatarsia. J Foot Ankle Surg. 1995;34(2):200-205. doi: 10.1016/S1067-2516(09)80045-8.

25. Schimizzi A., Brage M. Brachymetatarsia. Foot Ankle Clin North Am. 2004;9(3):555-570. doi: 10.1016/j.fcl.2004.05.002.

26. McGlamry E.D., Cooper C.T. Brachymetatarsia: a surgical treatment. J Am Podiatry Assoc. 1969;59(7):259-264. doi: 10.7547/87507315-59-7-259.

27. Choi H.I., Chung M.S., Baek G.H., Cho T.J., Chung C.T. Metatarsal lengthening in congenital brachymetatarsia: one-stage lengthening versus lengthening by callotasis. J Pediatr Orthop. 1999;19(5):660-664.

28. Jones M.D., Pinegar D.M., Rincker S.A. Callus distraction versus single-stage lengthening with bone graft for treatment of brachymetatarsia: a systematic review. I Foot Ankle Surg. 2015;54(5):927-931. doi: 10.1053/j.jfas.2015.02.013.

\section{AUTHOR'S AFFILATIONS}

Doron Keshet - MD, Pediatric Orthopedics, Ruth Children's Hospital, Rambam Health Care Campus, Haifa, Israel

Sari Salminen - MD, PhD, Pediatric Orthopedics, Ruth Children's Hospital, Rambam Health Care Campus, Haifa, Israel; Department of Pediatric Orthopaedics and Traumatology, University Clinic for Orthopaedics and Rheumatology, University of Trondheim (NTNU), St. Olavs Hospital, Trondheim, Norway

Mark Eidelman - MD, Pediatric Orthopedics, Ruth Children's Hospital, Rambam Health Care Campus, Haifa, Israel 